\title{
Inclusion of people with disabilities in the production system of a footwear industry
}

\author{
R.S. Bitencourt ${ }^{\mathrm{a}^{*}}$ and L. B. de M. Guimarães ${ }^{\mathrm{a}}$ \\ ${ }^{a}$ Graduate Program in Industrial Engineering, Federal University of Rio Grande do Sul, Av. Osvaldo Aranha 99 \\ 5 o andar, Porto Alegre, Brazil
}

\begin{abstract}
This article presents a study on the inclusion of people with disabilities (mainly mental impairment) in the workforce of a shoe company. The items that could impact on the success of inclusion were identified, and this included employees and other individuals taking part in the process. The inclusion process identified the interests, likes and dislikes of each employee with disabilities and correlated these with the activities available in the company. The case study evaluated the quality of the inclusion through interviews, questionnaires and an assessment of production efficiency. The results showed that inclusion did not adversely affect production, and highlighted that staff with disabilities do their work correctly. According to all employees interviewed, the inclusion of staff with disabilities improved the relationship of the boss with all of the staff and also led to the work environment being enhanced. The final evaluation is that the company's policy of inclusion succeeded.
\end{abstract}

Keywords: People with disabilities, inclusion program, work organisation

\section{Introduction}

A better place for everybody to live in is directly related to the creation of a new model of development for society as a whole, with social inclusion being one of the critical factors for the survival of any company in today's globalized market [13]. This context includes actions that foster the promotion of safety and health in the working environment and encourage diversity and the inclusion of groups of people who are still marginalized, such as people with disabilities [1,20,34-37]. These actions represent more than aspiring towards a fairer society. In fact, since 2000 , they have been part of an international commitment by those member countries of the United Nations who, in order to obtain an "Inclusive Society" in the next eight years (by 2015), are signatories to the "Millennium Development Goals" [13,16,34].

In Brazil, the effort to integrate people with disabilities into society and at work is set out in Federal Law $\mathrm{N}^{\mathrm{o}} 7.853$ [6], deemed the "Law of Quotas", which lays down a policy founded on reserving jobs for them in companies with one hundred or more employees, based on quotas that vary from $2 \%$ to $5 \%$, in accordance with the total number of employees. This form of widening work opportunities for those with disabilities has been questioned by authors such as Pastore [25] and Sassaki [29] who understand that, when a company takes on staff because it is obliged to do so by law, what occurs is that these people are assigned to marginal areas, and very often end up being stigmatized by their colleagues, an outcome that is clearly inhumane and counterproductive. Due to the persistence of misinformation and the inadequacy of provisions made for those with disabilities in terms of the architecture of the workplace, and means of transportation and communication, the national reality is that many productive people end up being set apart from the labour market. This article sets out to make a contribution towards changing this reality by presenting a case study in which it was possible to identify, using a participatory approach, items that can impact the success of including people with

\footnotetext{
* Corresponding author. Email: rosisb@ig.com.br tel: $+55513308-3948$ fax: $+55513308-4007$
} 
disabilities and which were later used in the planning of a barrier free factory [15].

\section{Case study}

The company studied is part of the Classico Group [10], which has been operating in the sports products segment since 1979. In 2008 it became part of the DASS Group. In Brazil, the Group comprises ten plants distributed throughout four states, employs 10,500 people and markets more than ten million pieces of sports articles annually [17]. The scope of this study covered gathering information from the shoe production unit in Venâncio Aires (the current DASS_Sport \& Style unit) in the state of Rio Grande do Sul. This unit was identified as relevant because, since 1999, it has encouraged the inclusion of people with mental, hearing and physical impairment on the shop floor. According to the Company's directors, social inclusion is now an integral part of the Company's commitment to social responsibility and also one of its missions. One example is its hiring of older people: the company has 23 employees over the age of 55 working in general services, and as checkers, porters and nursing assistants. Of those, $40 \%$ were hired only in 2005 . Regarding the hiring of people with disabilities, according to the company's Board reports, the process started prior to December 1999 (i.e. prior to the regulation of the Law of Quotas) when the industrial director witnessed a visually impaired person working in a mining company he was visiting in Minas Gerais, Brazil. At that time, Classico had only one employee who had a hearing impairment and who had been working in the Company for eighteen years. However, the town of Venâncio Aires had no entities dedicated to training or intermediating on behalf of unskilled people with a visual, physical or hearing impairment. This led the company to start hiring mentally impaired people through the Association of Parents and Friends of those with Special Needs (APAE) [2]. Of the total of six employees with disabilities, $4(65 \%)$ are people who are mentally impaired. Due to the fact that only APAE has the conditions to prepare people to be included in a production site, Classico has difficulty to comply with the "Law of Quotas", although the number of employees with disabilities has almost tripled in the last three years, two thirds of them being people who are mentally impaired. In addition, the company has shown interest in making information available on the process of including people with disabilities in its workplace.

\subsection{The work organization at Classico}

The production process consists basically of four steps: the preparation of the soles (pre-soles); the cutting out of the parts of footwear; stitching; and assembly of the footwear. The machines are arranged in the sequence of the process. There are no conveyor belts and the tasks are well defined. The criterion for grouping the equipment was established by similarity within the process. This arrangement was planned to enable a variety of items to be produced and also because of the uncertainty of demand, which thus allowed for the flexibility desired by the organization. Although the assembly unit is a line, internally, they are called work cells, each cell being responsible for the quality of products it produces. Those responsible for each sector are charged with passing on the programming of daily production to each cell, but are also active in production. Each cell has one person in charge and another called the "Joker" or wildcards who are employees trained to perform any of the activities of their cell, and who are able to solve routine work problems. The planning of production is drawn up based on clients' orders, i.e. production is dictated by needs, which means the cycle time is not fixed, thus allowing a variable rhythm of work.

Neither the person with a hearing impairment nor the person with a physical impairment need technical aids such as a wheelchair or crutches to perform his work in the Company. When it is necessary for there to be communication between the person with the hearing impairment and the team, they seek to understand each other by signs or in writing, as he can read and write in Portuguese. Furthermore, the equipment he operates has visual icons.

All the six company's employees with disabilities work directly in the footwear production, there being: one with a physical impairment works in the stitching sector (operating the pneumatic balance); one with a hearing impairment works in silk-screening; and four with mental impairment work in the sectors of cutting and assembly. Of these staff, those with hearing or physical impairments were the only ones who sought employment at their own initiative.

\subsection{The inclusion process at Classico}

The information gathered about the inclusion process of employees with mental impairment was 
mainly based on the interviews with the foremen of the cells, Company directors and the APAE team, who participated actively in the process at the time when it occurred. The inclusion process took place, basically, over six steps, conducted by the APAE team: a) identifying and evaluating tasks performed in the company; b) informing staff within the company about the process and preparing them to receive people with disabilities; c) briefing the person and his/her family; d) training this person by engaging with their skills, limitations and personal likes and dislikes; e) integrating the person into the workplace and supporting him/ her when he/she began his/her activities; f) weekly monitoring of this person until he/she was declared to be in no need of such regular monitoring and; g) quarterly reviews after this person is declared fully apt by the psychologist who conducts monitoring in the company.

During the APAE team's initial visits, at the stage of identifying and evaluating the tasks performed, they considered the company's HR suggestions of what activities seemed appropriate: putting in shoelaces, stuffing shoes with a wad of paper at the end of the shoe manufacturing process, assembly of shoe boxes, transporting shoes from one sector to another, preparing the footwear (initial phase) and tracing the height of the footwear. As to the choice of activities, the APAE and HR teams, together, took account of some reasons that could hinder the process of inclusion or even the training of people with disabilities to perform the activities. Tasks were eliminated that could put these people at risk, at least on their first engagement, so activities were excluded which might involve the operation of machinery or tasks incompatible with the skills of this staff. The effort was therefore made to focus on choices that might offer the greatest safety to the individual, thus minimizing the risks of accidents at work. The interests and personal likes and dislikes of each person were identified and correlated with the activities available in the company. The employees who were to work with the staff with disabilities were also trained, including those in supervisory and management positions. There was a need to conduct weekly psychological monitoring of the person with disabilities, especially at the start of the process and until it was effectively safe for him or her to be "discharged" from this procedure. Thereafter, monitoring began to be conducted monthly, or at longer intervals, depending on the case.

People with disabilities, who work in activities directly related to production, are assigned to the assembly sector. However, each of them is assigned to a cell, which has a different kind of work, that is, each of the three assembly cells works with an employee who is mentally impaired. The level of impairment was defined by APAE as follows: people with total bilateral hearing loss receives the instructions from the foreman of the cell on what activity they should perform; people with mild (low) cognitive impairment can perform more complex activities with no direct supervision; people with moderate cognitive impairment can work sequentially without needing, necessarily, to wait for an order from a supervisor. People with severe mental impairment has intellectual level below average, with limitations in all abilities described in Decree $\mathrm{N}^{\circ}$ 5.296 [6]: communication, personal care, social skills, integration in the community, health and safety, academic skills, leisure and work. They have to perform very simple activities, under supervision.

The inclusion of mentally impaired people demanded a gradual transfer of work based on the individual rhythm and modus operandi of operation of each such member of staff. Therefore, among the factors that contributed to the success of the inclusion, it can be said that flexibility offered by the cellular layout was a base element on several occasions. According to the foreman of the cell, the flexibility of the company with regard to production, i.e. its having a margin of error of $15 \%$ between what is planned and what is executed, is a factor that has contributed to the daily goals being met without generating situations of stress between the team and the people with disabilities. The fact that the rhythm of production is not dictated by a conveyor belt gave sufficient flexibility to allow work to be distributed at the rhythm appropriate to the learning demanded for each person with disabilities. Thus, although two people with mental disability (one with a severe disability and the other with a moderate disability) performed the same task of "assembling shoe boxes,", each assembled the boxes in the way they preferred. The task is suited to their skills and personal preferences, and no-one was seeking a greater pace of individual production. The average cycle time was 10.66 seconds for one and 14.66 seconds for the other, which characterizes the work as repetitive (Silverstein et al. [32] proposes that a work is repetitive when its cycle is less than 30 seconds).

According to the leader of the assembly cell, the task of assembling had been a factor of dissatisfaction for all workers: "the staff did not put up with doing this for more than a week." This is not a surprise 
since repetitive, non-imaginative and monotonous work is difficult to handle besides being correlated with the risk for developing work related musculosqueletal disordes (WMSD) [7,27]. However, according to the APAE team that monitors the case of the two people with mental disability who assemble shoe boxes, the chance of these people developing lesions should be low, because both of them like their work, feel motivated and happy. This might be due to the tendency of people with severe and moderate impairments to tolerate better the more routine, far from creative and repetitive work, because they have more difficulties when facing nonroutine situations. As to the employees with mild mental impairment, the APAE team could assign a more enriching job to them, one that is suited to their skills. In the case of the employee who works in the cutting sector, he performs a more complex job, which involves a larger set of activities, but despite this, he depends on an order from a supervisor.

The layout made it viable to work the team roster needed to meet the company's production targets and for the work of the people with disabilities when he/she could not do it to be performed by someone else. The inclusion process was conducted in such a way that the staff of the cell began to feel coresponsible for the success of the inclusion of the new member of the team, because the staff of the cell began to act more like a team.

\section{Method}

The gathering of data about the results of the inclusion process in the Classico footwear company took ten months (between August 2005 and May 2006). At that time, the plant at Venâncio Aires had 683 direct employees, with 600 of them working in activities directly related to production, six of whom had a disability. Staff from the sectors of production (cutting, stitching, doubling, frequency, assembly, pre-sole and silk-screening) and the sectors supporting production (stock-room, quality control, dispatch-receipt and maintenance), representing 92\% of the target population, took part in the study. Others who took part in the study were agents - both incompany ones (seven Classico employees from the Human Resources (HR) and production sectors) and those external to it (seven APAE employees) who were in charge of the inclusion process. The seven APAE professionals comprise a multidisciplinary team in the following areas of expertise: neurology, psychology, pedagogy, social work, and clinical medicine, including teachers and the woman director of the institution. These professionals' length of service in APAE varies between 10 and 15 years. $100 \%$ are female and they are between 36 and 57 years old. All participants in the study signed a written and informed term of consent

The analysis of the work in the company took place through direct and indirect observations (by videotaping the workers doing their work), with the identification of demands for inclusion following the first three stages of the Macroergonomic Design MD tool $[15,18]$ : a) identifying the user and the organized collection of information; b) prioritizing the ergonomic demand items (EDIs) identified by the user; and c) incorporating the specialist opinion. MD is a participatory tool for hearing the workers and managerial staff in order to identify the good and bad aspects of their work, and to propose solutions for making the work easier, more dynamic, autonomous and interesting, less fatiguing and more productive. The EDIs are identified through non-induced interviews with volunteers (in general 30\%) who are part of the target population. They are just asked to talk freely about their work and, if they agree with, the interview is recorded for later analysis at the University laboratory. Only the researchers take part of the interview session, and the tapes are never shown to anybody in the enterprise. In general, depending on the worker's preference, the interview sessions are done in groups (of 8 people in average). Based on the interviews, a questionnaire is built (adding some questions of interest of the researchers) and later fulfilled by all the target population. The questionnaires are anonymous and are never shown to anybody in the enterprise. They are also analysed in the laboratory.

The identification of the demands for inclusion of people with disabilities in the Classico company was conducted through non-induced interviews with 63 employees, in groups of 4 to 5 people (resulting in a total of 15 groups), volunteered as per their availability in production. The interview question was: "Say what you think about the inclusion of people with disabilities in the company (good and bad things)." The internal (seven people from Classico) and external (seven people from APAE) agents in charge of the inclusion process were also interviewed individually. These individuals were asked to "Report, from your point of view, what the process of inclusion in the company has been like. What did not work out and what should be done to improve this process." 
All the interviews were recorded, after authorization for this had been given. At the University laboratory, the tapes from the interviews with the workers and the internal and external agents in charge of the inclusion at Classico were analysed. This analysis considers the order and frequency in which the items were cited, and a weight is added related to its importance, as per the total sum of the interviewees. Following the MD tool, the more important items of the interviews (which are qualitative) with other not cited ones but which are considered important for the researchers, gave rise to the questionnaires to be answered by all employees. The opinion of each employee with respect to each of the issues of the questionnaire can be quantitatively measured (later, in the laboratory) by means of a mark on a continuous $15 \mathrm{~cm}$ long assessment scale of the questionnaire, as suggested by Stone et al. [33]. The intensity of each response varies between 0 (completely disagree and/or very bad) and 15 (fully agree and/or excellent). At the end of the questionnaire an open question was added in order to collect perceptions that were relevant to the study. The questionnaires were administered in groups of approximately 50 employees, who received an invitation card giving the time at which they were to appear in the meeting room in order to fill in the questionnaire. Before applying the questionnaires, the research team explained the purpose of the study being undertaken and the details of how to complete the questionnaires that are anonymous and confidential. They fulfil the questionnaire, handed out by the researchers, independently, with no supervisors in the room. Some employees with a low level of education were assisted in reading/ understanding certain questions, but the researchers sought not to induce responses. All 552 respondents signed a consent form for participating in the study.

With regard to the application of the questionnaire to the 6 employees with disabilities, the following procedures were necessary: a) identifying the person who are part of the target population: the department and number of individuals; b) identifying the type of impairment: hearing, physical, visual or mental; c) checking the accessibility of the site which was made available in order to apply the questionnaires, and; d) making necessary adjustments so that all staff with disabilities might participate and feel part of the process. There was no need to adjust the questionnaire for the employees with physical and partial hearing impairment (because he had been taught to read and write in Portuguese). In the case of employees with a moderate mental impairment, the questions were read and explained in a simplified manner, and they themselves measured their opinion on the scale. For individuals with a severe mental impairment, only a simulation of their participation was undertaken so that they might feel part of the process. It is worth noting that because these employees could not sign a consent form for participating in the study, APAE assumed the responsibility for their participation.

At the laboratory, the data from the questionnaires were tabulated and prioritized, and the weight of each EDI was generated by its arithmetic average. This article discusses only the results from the seven agents from APAE and the 34 people of the Classico staff working directly with the people with disabilities (8 working with people with physical disabilities, 15 working with the person with hearing impairment and 11 working with people with mental impairment). The questionnaires showed good internal consistency (Cronbach's Alpha= 0.71) [11] and were analysed by means of descriptive statistics and non-parametric statistical tests because data did not display normal distribution. The results from the Classico group were analysed with the KruskalWallis test in order to compare the responses as a function of the type of respondent (i.e., co-working with people with physical, hearing or mental impairment). The results with a statistical difference (p-value <0.05) were analysed with the nonparametric Tukey test to complement the averages comparison. The responses of the APAE group (7 people) and the whole Classico team working directly with the people with disabilities (34 people) were compared with the Mann Whitney U test.

\section{Results}

Mann Whitney U test showed that the importance perceived both by Classico and APAE groups in relation to achieve the inclusion of people with disabilities in the workplace differ: on the necessity to have good knowledge of the impairments of these people in order to include them better in the work environment $(\mathrm{p}=0.41)$; on the necessity for there to be suitable professional monitoring during the process of including people with disabilities in the company $(p=0.49)$ to conduct appropriate professional monitoring to check if the inclusion is working out correctly $(\mathrm{p}=0.009)$; on the necessity to have good knowledge of the job to be performed in order to include them in the company $(p=0.009)$; on 
the necessity to have good knowledge of the skills of the disabled people in order to include them better in the work environment $(\mathrm{p}=0.009)$; and on the necessity that the work team is trained to receive people with disabilities $(\mathrm{p}=0.001)$. The APAE group values those items more than the Classico group.

With regard to the Company's access infrastructure for inclusion, the Classico's employees consider the workstations and the building are appropriate while the APAE team is not as satisfied $(p<0.001)$. According to the Company's directors, when the current building was designed, the middle managers stated "that it had to be accessible, so that the company could receive visitors with disabilities".

In relation to issues concerning the preparation of both the team and management to receive a member of the staff with disabilities as well as on how to prepare this person to perform his/her work, the perception of the Classico staff is that the boss knows how to manage the person with disability and has also been prepared to work with such people. However, Mann Whitney U test showed that the Classico group and the APAE one do not agree, to the same extent, that superiors (bosses, foremen, etc.) are prepared to work with other people with disabilities $(p=0.05)$. The employees feel they were sufficiently prepared to work with a member of the staff with disabilities. Kruskall Wallis test showed that the perception of the staff working with a mentally impaired person differ from the staff who work with people with physical or hearing impairment $(p=0.009)$ about the possibility of training him/her to perform other jobs in the company. The position of the latter groups is more favourable as to the possibilities of training them.

In relation to team management and the worker with disability, all respondents agree (there was no significant statistical difference among the answers) that the boss makes the same demands of the staff with disabilities as of other staff but, on the other hand, the staff with disabilities has privileges that all other staff should have such as: trips to the bathroom and to drink water. It is worth stressing that despite the foremen of the cells having received guidance on the fact that one of the side-effects of some medicine used by mentally impaired staff makes them more thirsty and, consequently, their needing to make more trips to the bathroom, this does not mean to say, necessarily, that other staff do not also have this need and this should be dealt with individually and flexibly. Kruskall Wallis test showed a difference $(p=0.025)$ between the opinions of the team working with the hearing impaired person and the teams working with mental and physical impaired people about the question "the boss never asks the people with disabilities to do unnecessary jobs". The former understands that this is not true for the hearing impaired person.

The results on the relationship between the member of the staff with disabilities and members of the team showed that all the interviewees agree (there was no significant statistical difference among the answers) that they like working with this person, and that they get on well with co-workers and with the boss. Moreover, the entry of the person with disabilities into the team improved the relationship of the boss with his work team. All agree that with the entry of the people with disabilities, the working environment became better. Many reports corroborate the positive view on the inclusion of the member of the staff with disabilities. However, the Mann Whitney $U$ test showed that the Classico group and the APAE one do not agree, to the same extent, that the work team likes working with the person with disabilities $(p=0.021)$.

The Company's and APAE staff understand that the conditions of access provided by the municipality are good only for the EDI work environment. They gave scores below average (7.5) for the built environments, for the conditions of access in the streets and for accessibility into schools; this latter issue addressed matters ranging from access conditions to the preparation of teachers. For the APAE team, all the items are unsatisfactory. The Mann Whitney $U$ test showed that the responses of the APAE group and the Classico one are statistically different about the conditions of the environments to receive people with disabilities $(\mathrm{p}<0.001)$ and about the conditions of access to the built environments of Venâncio Aires to receive these people $(\mathrm{p}=0.008)$. The APAE group is less satisfied with all these items in comparison to the Classico group. These data, when observed in isolation, indicate the provision of accessibility by the municipality is low.

Considering the results of the productivity and quality of the work of the staff with disabilities, the APAE team considers that there is no limit to seeking the productive inclusion of a person with severe mental impairment in an industrial environment with low risk involved. For the head of HR, the mentally impaired workers give exceptionally high value to the work and in some cases stand out from other employees. The Company does not have a record of individualized control per cell at the time the inclusions occurred and the company has never been interested in measuring the productivity of mentally 
impaired staff or in comparing their performance with that of other staff. Although it could not be statistically proved, due to the lack of productivity data, both the Classico group as a whole and APAE perceive an improvement in the productivity of the team with the inclusion of people with disabilities: production was not adversely affected and the member of the staff with disabilities does his/her job correctly. However, the Classico team that works with the person with physical impairment understands that his inclusion had a negative impact on production (Kruskall-Wallis test, $\mathrm{p}=0.023$ ).

Throughout the process of inclusion there were unforeseen occurrences, deviations, problems and readjustments in the form of inclusion, and each case was dealt with individually. Nevertheless, those involved both from APAE and the Company say they have learned a lot from the experience, describe the process of inclusion as having been successful and that the benefits have exceeded expectations. The success of the inclusion of people with disabilities can be perceived mainly because the Company obtains a real return on the work they perform, they are like other employees, with deadlines and targets to be met. It should, however, be understood that there are individual differences and these differences should be respected in the same way as we should respect the differences of any other person. To do so, it is necessary to find activities that match the potential that each has to offer. In this process, the commitment of the Company's directors was crucial, since without a real desire to include, any deviation in the initial planning could have been used as a justification to abort the process. The results show a tendency of the APAE professionals to declare them to be more dissatisfied with the demands of accessibility than the Classico's employees are. This may be a reflection of their high expectations, since their goal is to seek the continuous improvement of environments for the benefit of the people with disabilities. Greater satisfaction with the work environment by these people is not an isolated result of this research since it is in accordance with other studies $[14,26,28]$. Having a job is in itself something few people achieve in a country that does not give value to the ordinary worker in general, and especially not to those with disabilities.

In relation to the importance perceived both by Classico and APAE in relation to achieve the inclusion of people with disabilities in the workplace, the results indicate that it is necessary to have a procedure for inclusion, which may require external means of support or assistance throughout the implementation of the inclusion process. The understanding of the necessity of considering the abilities, capacities and limitations of these people has been the aim of different ergonomic studies $[3,8-$ $9,12,14,19,21-24,30,31]$.

\section{Conclusion}

This article has presented a study in a footwear company that employs people with disabilities in activities directly related to the production sector. In a participatory manner, together with the individuals who participated in the process of inclusion or who currently work with the staff with disabilities, it was possible to identify the demands that might contribute to the success of inclusion.

Despite the small number (six) of employees with disabilities, for the Company staff, the inclusion was successful. They like to work with the staff with disabilities and consider that their inclusion improved both the boss relationship with the whole team and the working environment. Regarding production, the results indicate that the inclusion of the staff with disabilities has no adverse effect because they do their job properly.

It can be deduced that the success of the inclusion of people with disabilities depends on the characteristics of the relationship between the production and the personnel systems, i.e., how the work system is designed. The rhythm of production, which in this Company is not dictated by a conveyor belt, gave enough flexibility to allow for inclusion to take place gradually, and to respect individual differences. The employees with mental disabilities were assigned to the assembly cells and the flexibility offered by the cellular arrangement as well as allowing work to be distributed in accordance with the rhythm appropriate for each person with disabilities was decisive for the inclusion process. The cell team roster has allowed both the demands of production to be met and those arising from staff with disabilities themselves, in the initial stages of the inclusion process.

The experience this company had is a differential for this study, not least because the demands related to the inclusion of disabled people, mainly the mentally impaired, are barely addressed by national legislation measures. Among the issues already discussed in the literature, this study reinforces the importance of meeting demands such as: there being teams of specialists to implement and/ or support the 
process of inclusion and the effective commitment to inclusion by the company's board of directors.

\section{Acknolewdgements}

The authors are grateful to Classico, APAE and to all volunteers engaged in this research, which was partly funded by the Brazilian Federal Agency for the Support and Evaluation of Graduate Education (CAPES)

\section{References}

[1] Americans with Disabilities ACT - ADA, The Americans with disabilities Act. http://www.eeoc.gov/ada/, Accessed 10.07.11, 1990.

[2] Associação de Pais e Amigos dos Excepcionais - APAE, Survey undertaken with the APAEs by area served (in Portuguese). http://www.apaeceara.org.br/repositorio/DF/ apae final.doc, Accessed 21.11.05, 05, 2005.

[3] P. Bengtsson, et al., Computer-aided planning of production, working and residential environments, Int. J. Ind. Ergon,17 (1), 59-68, 1996.

[4] M. C. K., Bissigo, Nível de satisfação de pessoas portadoras de deficiência ambulatória com trabalho e com as condições de acesso a empresas de Caxias do Sul (in Portuguese), Dissertation (MEng), Federal University of Rio Grande do Sul, 2004.

[5] R. S., Bitencourt and L. B. de M., Guimarães, A conceptual model proposed for the planning of industrial facilities free from barriers, Proceedings of the XIV International Conference on Industrial Engineering and Operations Management, ABEPRO, Rio de Janeiro, 2008.

[6] Brazil, Federal Law N 7.853 approved on 24/10/1989 and regulated by Decree 5.296 of December 2, 2004

[7] P., Carayon, M.J. Smith, and M.C., Haims, Work Organization, Job Stress, and Work-Related Musculoskeletal Disorders, Human Factors, 41 (4), 644-663, 1999.

[8] C.F., Chi, J.S., Pan, T.H., Liu, Y., Jang, The development of a hierarchical coding scheme and database of job accommodation for disabled workers, Int. J. Ind. Ergon, 33 (5), 429-447, 2004

[9] C.F., Chi, A study on job placement for handicapped workers using job analysis data, Int. J. Ind. Ergon, 24 (3), 337-351, 1999.

[10]Classico, Classico Group, http://www.Classico.ind.br Accessed 10.12.05, 2005.

[11]L. J., Cronbach, Coefficient alpha and the internal structure of tests, Revista Psychometrika, 16, 297-334, 1951

[12]J., Eriksson and G., Johansson, Adaptation of workplaces and homes for disabled people using computer-aided design, Int. J. Ind. Ergon, 17 (2), 153-162, 1996.

[13]Ethos Institute, O Compromisso das Empresas com as Metas do Milênio (in Portuguese), São Paulo: Instituto Ethos Empresa e Responsabilidade Social, 2004.

[14]R. J., Feeney and M. D., Galer, Ergonomics research and the disabled, Ergonomics 24 (11), 821-830, 1981.

[15]F. S., Fogliatto and L. B. de M., Guimarães, Design macroergonômico: uma proposta metodológica para projetos de produto, Produto \& Produção 3 (3), 1-15, 1999

[16]Ford Foundation, Strengthen Democratic Values, Reduce Poverty and Injustice, Promote International Cooperation and Advance Human Achievement, http://www.fordfound.org Accessed 05/11/03, 2003.

[17]Grupo Dass, Histórico: Dass Dilly Classico (in Portuguese) http://www.grupodass. com.br/ Accessed 05/01/08, 2008.
[18]L. B. de M., Guimarães and F. S., Fogliatto, Macroergonomic design: a new methodology for ergonomic product design, Proceedings of the 2000 International Ergonomics Association Conference, San Diego, v. 2, p. 328-328, 2000.

[19]J. M., Guralnik and L., Ferrucci, Assessing the building blocks of function: utilizing measures of functional limitation, Am. J. Prev. Med, 25 (3), sw. 2, 112-121, 2003.

[20]International Labour Organization - ILO, The rights to decent work of persons with disabilities http://www.ilo.org/public/english/region/asro/bangkok/library/ about.htm Accessed 15/04/2005, 2004.

[21]H., Lai and Y., Chen, A study on the blind's sensory ability, Int. J. Ind. Ergon, 36 (6), 565-570, 2006.

[22]C., Miralles, J.P., García-Sabatera, C., Andrés and M. Cardos, Advantages of assembly lines in Sheltered Work Centres for Disabled, A case study, Int. J. Prod. Econon, 110 (1), 187-197, 2007.

[23]K., North and W., Rohmert, Job analysis applied to the specialist needs of the disabled, Ergonomics 24 (11), 889-898, 1981.

[24]E., Nowak, Workspace for disabled people, Ergonomics 32(9), 1077-1088, 1989

[25]J., Pastore, Oportunidades de Trabalho para Portadores de Deficiência (in Portuguese), 2. ed., LTR, São Paulo, 2001.

[26]S. M., Poloni, Escutas, olhares e falas sobre as diferenças: o espaço real do portador de deficiência física no mundo do trabalho, segundo as percepcões dos envolvido (in Portuguese), Dissertation (MEng), Federal University of Rio Grande do Sul, 2004.

[27]I., Rivilis, D. C., Cole, M. B., Frazer, M. S., Kerr, R. P., Wells and S., Ibrahim, Evaluation of a participatory ergonomic intervention aimed at improving musculoskeletal health, Am. J. Ind. Med., 49, 801-810, 2006.

[28]N. M. F., Rosa, As relações de trabalho da PPD: um estudo inclusivo (in Portuguese), Dissertation (MEng), Federal University of Rio Grande do Sul, 2004.

[29]R. K., Sassaki, Inclusão: construindo uma sociedade para todos (in Portuguese), 3. ed., WVA, Rio de Janeiro, 1999.

[30]H. N. J., Schifferstein and P. M. A., Desmet, The effects of sensory impairments on product experience and personal wellbeing, Ergonomics 50 (12), 2026-2048, 2007.

[31]D. E., Shrey and R. E., Breslin, Disability management in industry: a multidisciplinary model for the accomodation of workers with disabilities, Int. J. Ind. Ergon, 9 (2), 183-190, 1992

[32]B.A. Silverstein, L.J. Fine and T.J. Armstrong, Hand wrist cumulative trauma disorders in industry, Occup. Environ. Med., 43: 779-784, 1986.

[33]H. Stone, J. Sidel, S. Oliver, A. Woolsey and R.C. Singleton, Sensory evaluation by quantitative descriptive analysis, Food Technology, 28 (1), pp. 24-34, 1974.

[34]United Nations, What are the Millennium Development Goals? http://www.un.org/millenniumgoals/ Accessed 16/05/08, 2008.

[35]University at Buffalo, The state University of New York Center for Inclusive Design and Environmental Access, School of Architecture and Planning, Universal Design New York, 4.1e Workplace Facilities, http://www.ap.buffalo.edu/idea/udny/Section4-2e.htm Acessed 17/06/11, 2001.

[36]University of North Carolina, The Center for Universal Design. http://www.design.ncsu.edu/cud/about ud/udprinciplestext.htm Accessed 22/07/11, 1997.

[37] World Health Organization - WHO, http://www.who.int/research/en/ Accessed 11/03/08, 2008. 